\title{
PELATIHAN PENYIMPANAN DIGITAL SISWA PADA SMA DAN SMK GALA JUARA BEKASI
}

\author{
Adi Muhajirin, Dani Yusuf, Dwipa Handayani, Mukhlis, Tyastuti Sri Lestari \\ Fakultas Teknik, Universitas Bhayangkara Jakarta Raya \\ Email : adi.muhajirin@dsn.ubharajaya.ac.id
}

\begin{abstract}
The presence of the internet in everyday life has changed the way modern people live. The field of administrative work is the most changing field. One of the changes in the way the administration works is with the concept of paperless office or paperless office concept. Schools as a means of education can take advantage of the concept of paperless office to reduce operational costs and improve the quality of information services valid student data/i. The object of this devotion, addressed to SMA and SMK gala champions who do not have digital-based storage. providing training to senior high school and vocational high school staffs in having valid data and reducing paper usage. The data were collected by library study and observation. SMA and SMK Gala Juara experienced obstacles in the recording of complete student data due to lack of human resources who have the ability in the field of IT and lack of time allocation in preparing reports. The purpose of this dedication is to help SMA and SMK Gala Juara to minimize misunderstandings on student data recording digitally and integrated.
\end{abstract}

Keywords: Paperless Office, Green ICT, Integrated

\section{PENDAHULUAN}

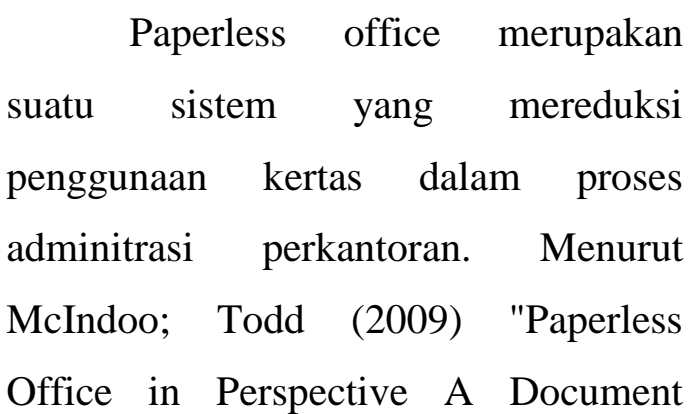
Management System for Today", Paperless office is also a metaphor for the touting of new technology in terms of 'modernity' rather than its actual suitability to purpose.

Saat ini layanan administrasi adalah layanan yang hampir ada di semua instansi termasuk di instansi pendidikan. Pada sekolah layanan administrasi terbanyak adalah layanan administrasi pendataan siswa yang umumnya dilakukan oleh bagian tata usaha sekolah. Walaupun secara fisik kegiatan administrasi akademik dan kemahasiswaan sangat banyak, namun kegiatan administrasi ini umumnya adalah kegiatan rutin yang berulang setiap tahunnya.

Kurangnya infrastruktur dan aplikasi pendukung teknologi informasi dilingkungan ditambah dengan budaya dan perilaku yang masih enggan untuk memanfaatkan teknologi informasi 
dalam mendukung kegiatan sekolah. Menurut Sigit Dewandaru; Dimas (2013) "Perlu sebuah komitmen serta inovasi dari teknologi informasi yang dapat memuncul rasa ketertarikan terhadap teknologi yang akan digunakan"

Dengan sifatnya yang relatif tetap dan berulang, maka kegiatan di tata usaha ini dapat diotomasi dengan bantuan internet dan sistem informasi.

Dengan adanya sistem informasi yang bersifat online maka layanan dapat dilakukan lebih mudah, cepat, dan akurat, namun tidak menggunakan banyak kertas. Dimana Total siswa/i SMK 414 orang dan Total siswa/i SMA 148 orang yang menjadi landasan bahwa perlunya aplikasi arsip digital untuk meringankan pekerjaan staff TU. Aplikasi Arsip ini meliputi login admin, entry data siswa dan upload berkas kebutuhan sampai dengan pelaporan data siswa. Kendala penerapan teknologi informasi dan komunikasi (TIK) antara lain kurangnya ketrampilan IT menggunakan sistem informasi arsip digital ini. Seperti yang terdapat dalam Menurut Venkatesh, Morris, Davis, \& Davis, (2003) "Perceived usefulness diharapkan dapat dipengaruhi oleh perceived ease of use.
Hal tersebut dikarenakan semakin mudah menggunakan sistem, maka semakin bermanfaat".

\section{METODE}

Dalam pelaksanaan kegiatan ini, penulis menerapkan beberapa metode, yaitu :

\section{Metode Persiapan}

a. Tahap persiapan berupa identifikasi pada staff tata usaha, siswa-siswi dan perwakilan guru yang belum berpengalaman dengan arsip digital.

b. Persiapan bahan slide materi, aplikasi arsip digital dan instruktur pelatihan yang kompeten yang akan dilaksanakan pada program pengabdian kepada masyarakat.

c. Persiapan mahasiswa yang terlibat pada kegiatan ini, dengan aspek kompetensi aplikasi berbasis web

\section{Metode Pelaksanaan}

a. Peserta pengabdian diberikan wawasan mengenai pentingnya manajemen arsip dalam membuat laporan arsip siswa. Langkah pertama diselenggarakan melalui metode ceramah selama 2 Jam 
b. Penggunaan E-Arsip ini user friendly, sehingga mudah digunakan dan tidak memerlukan kemampuan bahasa pemrograman yang sulit untuk mengoperasikan dalam mengunggah berkas di http://iam-

solution.com/abdimas/dashboard

\section{Metode Pelaporan}

Tahap pelaporan akhir untuk melaporkan bagaimana pelaksanaan hasil pelaksanaan kegiatan di SMA dan SMK Gala Juara Bekasi.

\section{HASIL DAN PEMBAHASAN}

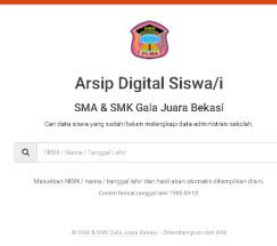

Gambar 1.1 adalah gambar halaman pada e-arsip yang telah kami buat dengan memasukan NISN/ Nama/ Tanggal Lahir untuk pencariannya agar lebih mudah.

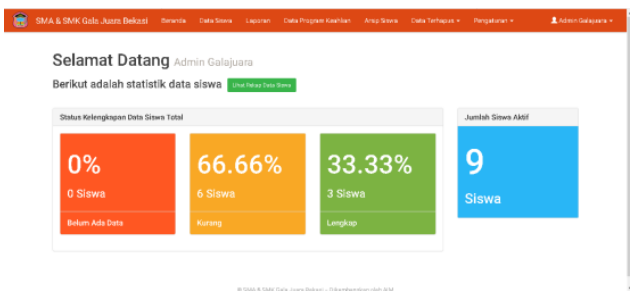

Gambar 1.2 Dasboard Admin
Dalam gambar 1.2. dasboard admin menjelaskan bahwa terdapat keterangan siswa belum ada data, kurang data, data lengkap dan total siswa yang aktif. Dan terdapat menu beranda, data siswa, laporan, data program keahlian, arsip siswa, data terhapus, pengaturan dan admin galajuara.

\section{KESIMPULAN}

Berdasarkan hasil pelaksanaan kegiatan PKM yang telah dilakukan, dapat diambil beberapa kesimpulan sebagai berikut;

1. Telah dilakukan pelatihan mengenai E-Arsip kepada peserta pelatihan.

2. Peserta dapat meningkatkan pengetahuan sekaligus sebagai stimulasi agar peserta pelatihan lebih kreatif dalam menggunakan berkas penting dalam membackup data dan menyimpann dalam e-mail

3. Berdasarkan pelatihan PKM yang telah dilakukan maka disarankan:

1. Keterlibatan yayasan/ pimpinan untuk memperispakan investasi jangka panjang terhadap ICT.

2. Diperlukan pelatihan terhadap staff tata usaha, guru, dan siswa-siswi tehadap peduli 
lingkungan dengan cara membuat arsip digital atau earsip demi terciptanya go green in school.

Acknowledgements

Penulis secara khusus mengucapkan terima kasih yang sebesar - besarnya kepada semua pihak yang telah membantu. Penulis banyak menerima bimbingan, petunjuk dan bantuan serta dorongan dari berbagai pihak, baik yang bersifat moral maupun material. Pada kesempatan ini penulis menyampaikan rasa terima kasih yang sebesar besarnya kepada :

1. Allah SWT dengan segala rahmat serta karunia-Nya yang memberikan kekuatan bagi penulis dalam menyelesaikan pengabdian masyarakat.

2. Kepala Sekolah SMA \& SMK Gala Juara beserta staffnya yang telah memberikan waktu serta kesempatan bagi tim pengabdian masyarakat Universitas Bhayangkara Jakarta Raya

3. Tim Pengabdian Masyarakat yang telah memberikan support serta kerjasamanya selama pelaksanaan pengabdian masyarakat.

Semoga Allah SWT senantiasa membalas semua kebaikan yang telah diberikan. Semoga pengabdian ini dapat bermanfaat bagi tim pengabdian umumnya kepada para pembaca.

\section{REFERENSI}

Dewandaru DS, 2013, "Pemanfaatan Aplikasi E-Office untuk mendukung Penerapan EGoverment dalam kegiatan perkantoran studi kasus: PUSLITBANG Jalan dan Jembatan, Seminar Nasional Teknologi Informasi dan Multimedia, Yogyakarta

McIndoo; Todd, 2009 "Paperless Office in Perspective A Document Management System for Today", Paperless office is also a metaphor for the touting of new technology in terms of 'modernity' rather than its actual suitability to purpose

Venkatesh, V., Morris, M.G., Davis, G.B., dan Davis, F.D, 2003, "User acceptance of information technology: toward a unified view”, MIS Quarterly, 27 